\title{
Waitangi Precinct: Competition Entry, Wellington, 2005
}

\section{KTAAW: Kerstin Thompson Architects, Architecture Workshop}

Following an initial call for expressions of interest, five firms and teams were invited to develop entries for the Waitangi Precinct: Japanese architect Shin Takamatsu; John Wardle Architects from Melbourne; Oosterhuis_Lenard and UN Studio, both from the Netherlands; and the transTasman team of KTAAW (Wood, 2005). John Wardle won the competition for Sites I, 2 and 3 and UN Studio, for Site 4 .

Architecture Workshop, in collaboration with Isthmus Group and Tonkin \& Taylor, received both accolades and an NZIA Supreme Award for Architecture for their Oriental Bay Enhancement project in 2006, Oriental Bay being but a stone's throw from the Waitangi Precinct. These two urban design projects, both producing collaborative architecture and landscape architecture outcomes, demonstrate that the Wellington City Council, and its subsidiary Wellington Waterfront Ltd., are committed to improving the quality of that city's urban public spaces and the accessibility and experience of the Wellington waterfront, thus making the lack of comparable initiatives in certain other New Zealand towns and cities all the more noticeable. - Eds.

\section{Architects' Statement: New grounds for play}

Our proposal offers new grounds for play, for the city of Wellington. Imagined as an extension of Waitangi Park, it reconnects earth, sky and sea and strengthens the city and water edges of the precinct.

Our scheme provides a gentle topography held and framed by robust buildings, with new opportunities for living, working and playing. It achieves a balance between the development of the waterfront and its continued enjoyment by the public. The careful siting and scale of our suite of buildings and landscapes maximises the experience of the waters edge, while maintaining precious view lines from within the park and the city's north-south streets. This proposal offers a place from which to consolidate Wellington's position as the cultural capital of New Zealand, and new ground on which to play out the city's future.

\section{Taking a stroll}

Imagined as a promenade, in celebration of the established walking patterns of Wellington, the design traces a primary path from Oriental Parade alongside the historic sea walls of Port Nicholson Yacht Club, under and over our folded ground, past the graving dock, beside the Chinese garden, through our gallery up to the marae of Te Papa. The integration of buildings and landforms orchestrates a journey which frames the harbour and city, and provides intimate and open spaces for repose.

\section{Celebrating city and sea}

The proposal occupies two sites and each defines a key edge of the Waitangi precinct. Site 1/2/3 forms the waters edge and Site 4 , the city edge. They are designed to be in conversation with each other across the park.

The waters edge is celebrated through our lyrical folded ground: a trafficable roof that gently rises up from Waitangi Park, forming a view corridor to the Tararua Mountains. A new horizon, it frames the harbour and creates an urban promontory to complement the field of the park. Underneath is a substantial portion of the program, including cafes, restaurants, a fish market and deli.

The city edge is defined by the gallery, a robust timber framed structure referencing local construction methods and the hardiness of marine structures. It is an exemplary demonstration of contemporary environmental design. As a carapace, it forms a climatic buffer to protect the heat and light sensitive galleries which are held within its volume. The gallery is urban in character, providing a major space 
for cultural events, defining the city edge of the site, and also forming the primary edge to the view corridor from Tory Street to the harbour. The Hostel building addresses Cable Street.

\section{New ecologies}

With this landmark project, we have sought to use architecture and landscape to contribute to the larger sustainable future of the city. We propose a constructed environment: one that, as a sophisticated ensemble of buildings, landscapes and site infrastructure, forms a new ecology that supports events, people and place in a balanced relationship. Green features of the proposal exploit Wellington's climatic conditions for carbon neutral technologies.

\section{City edge - environmental statement}

Contemporary art galleries are energy intensive, due to the requirements for conservation and close environmental control. Our response closely integrates architectural design, the 'positively Wellington' climate, the natural sources of energy local to the waterfront site, and the organization and topography of the site elements. An 'eco-skin' is used to absorb heat in winter and to reflect heat in summer. Natural day-lighting is provided to the main circulation routes. The building will be heated and cooled using energy and water efficient reversible heat pumps, fed from the natural seawater gradient beneath the site, with bores for supply and recharge. The opportunity exists to interlink the plant and energy management systems with those of the main Te Papa complex.

\section{Waters edge - environmental statement}

Energy use is minimized, by the use of double aspect apartments with winter garden balconies and maximum access to natural light and ventilation. The long-life building enclosure has best practice levels of thermal insulation, and low emissivity double glazing. Each apartment is also provided with solar hot water panels integrated into the roof structure. Water conservation will be encouraged by the use of ultra-low flow sanitary fixtures, and by roof-water collection and recycling for toilet flushing. Low energy lighting and appliances complete the strategy.

Green transport solutions will also be encouraged as the development forms an important boardwalk node in the pedestrian network of Wellington. Car parking will be minimized, within the commercial constraints of the development and, where provided, will be on a 'small car' basis. Secure cycle storage will be provided for residents, with additional facilities for the general public. The option exists to provide facilities for re-chargeable electric vehicles.

The design provides a new paradigm for mixed use development in Wellington.

\section{References}

Wood, P. (2005). Waitangi Park Competition. Architecture New Zealand (NovemberDecember), 18-23. 


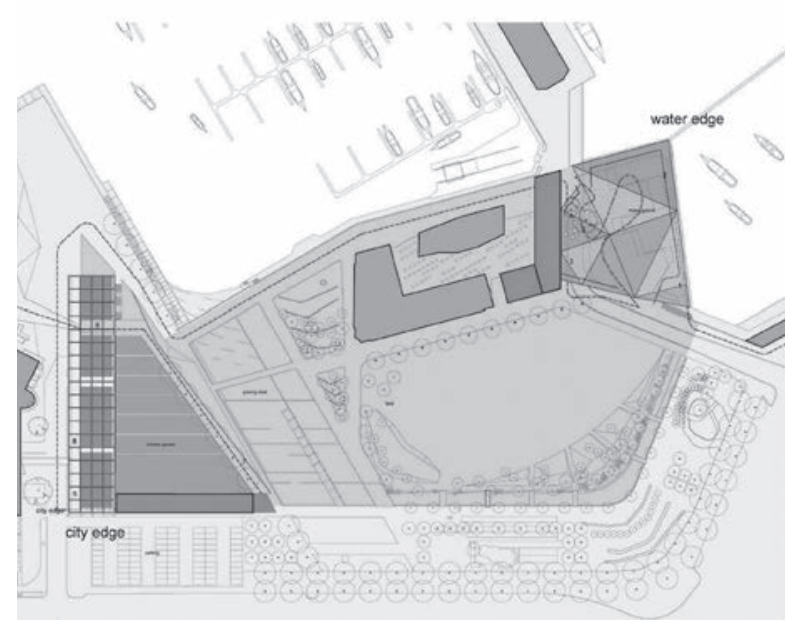

Site plan identifying the waters edge (Site 1/2/3) and the city edge (Site 4). The south-east corner (bottom right in the image) is now Wraight Athfield's award-winning Waitangi Park.

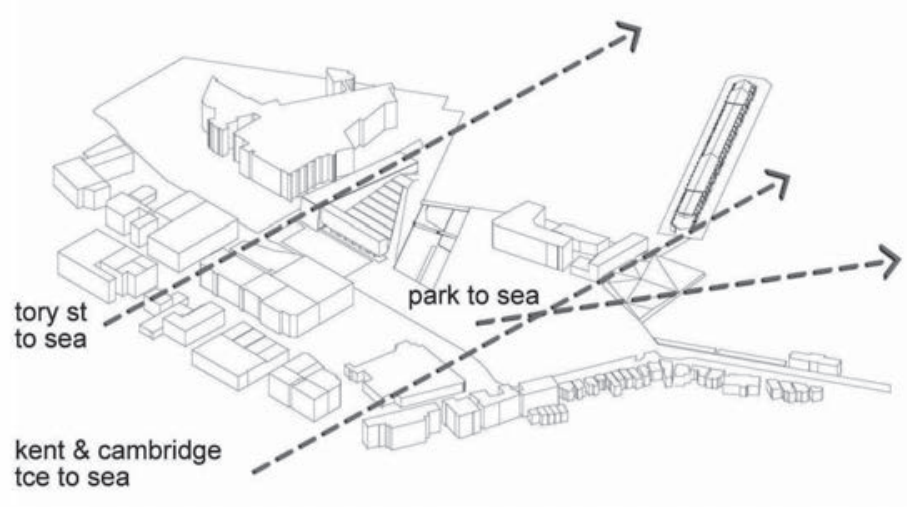

Site diagram identifying the two primary view corridors through the precinct.

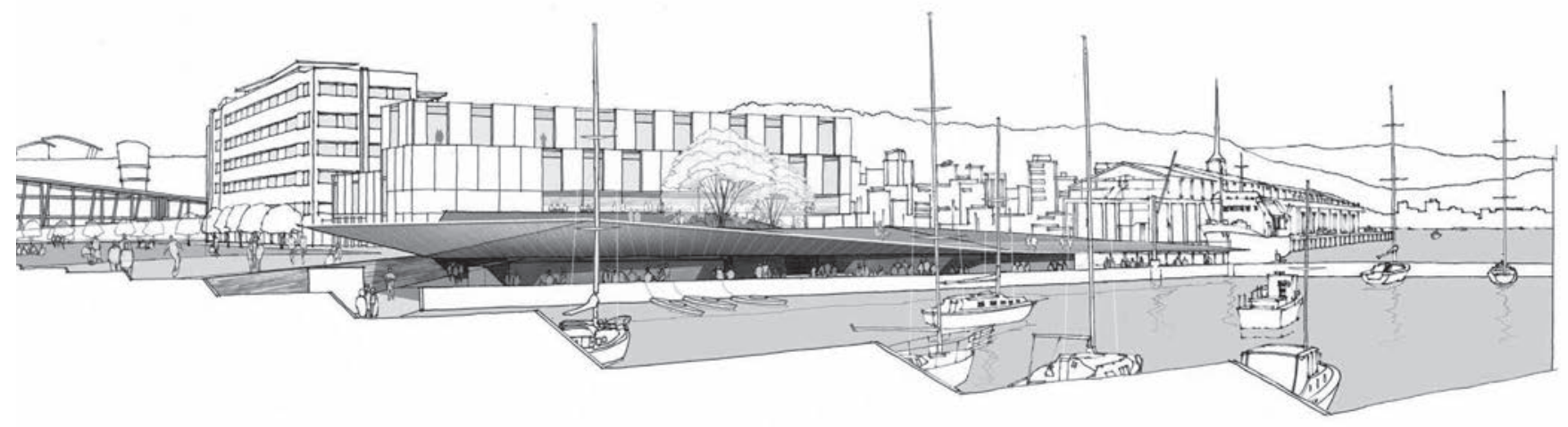

The waters edge facilities, with the folded ground plane in the foreground, the old Herd Street Post Office and the Overseas Terminal behind, and proposed gallery building on the far left.

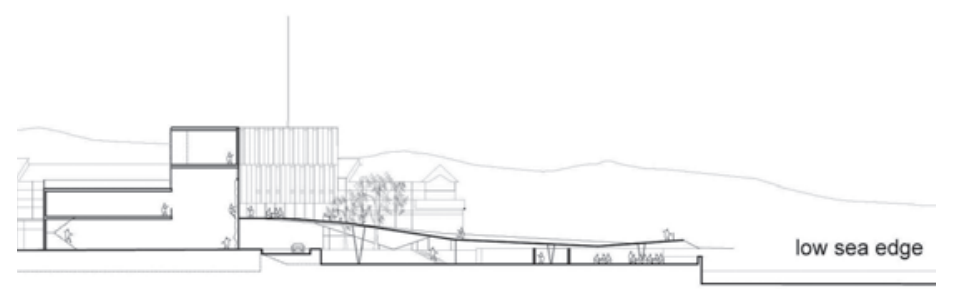

The section through the waters edge site shows reduced height near the sea.

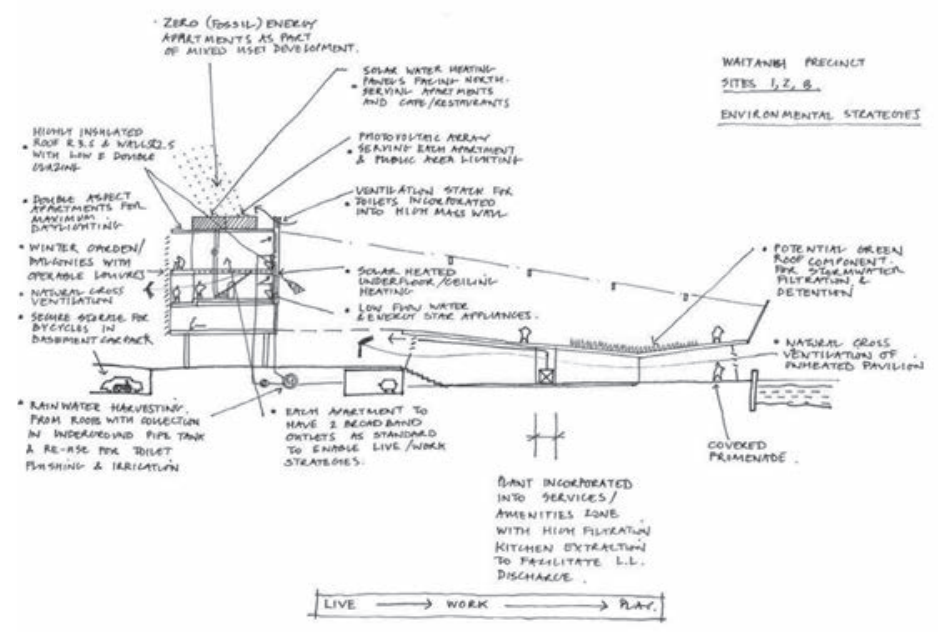

Sectional diagram showing the environmental strategies incorporated into the folded ground plane and apartment building, including solar and photovoltaic panels, rainwater harvesting, insulation, double glazing, natural cross ventilation and bicycle storage.

\section{Folded ground plane opaque / light filtered}

Program wall fish market / deli / restaurant / rec hire

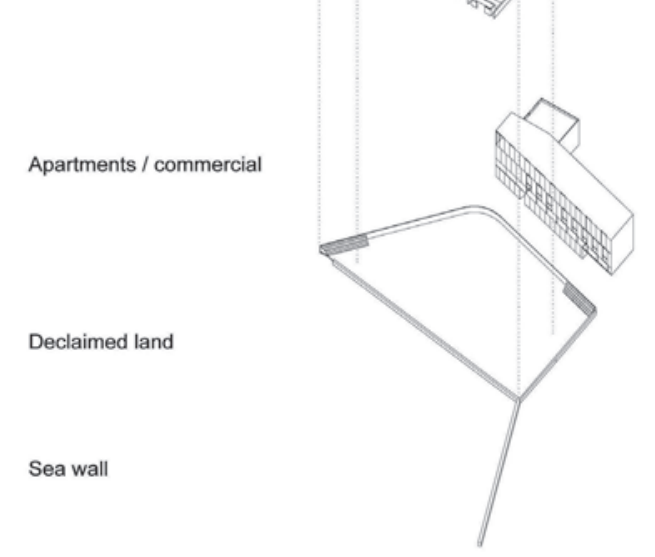

Exploded axonometric of the key elements of the waters edge site: sea wall; declaimed land; apartments and commercial outlets; the 'program wall' with fish market, deli, restaurant and recreational hiring facilities; and the folded ground plane, filtering the light to spaces below. 


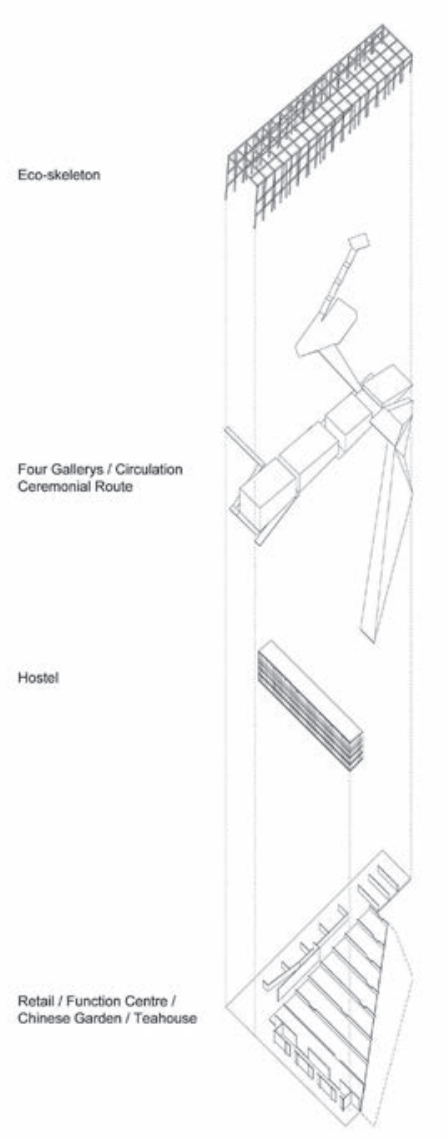

Above: Exploded axonometric of the key elements of the city edge. Below: The section through the city edge part of the proposal shows increasing height towards the city centre.
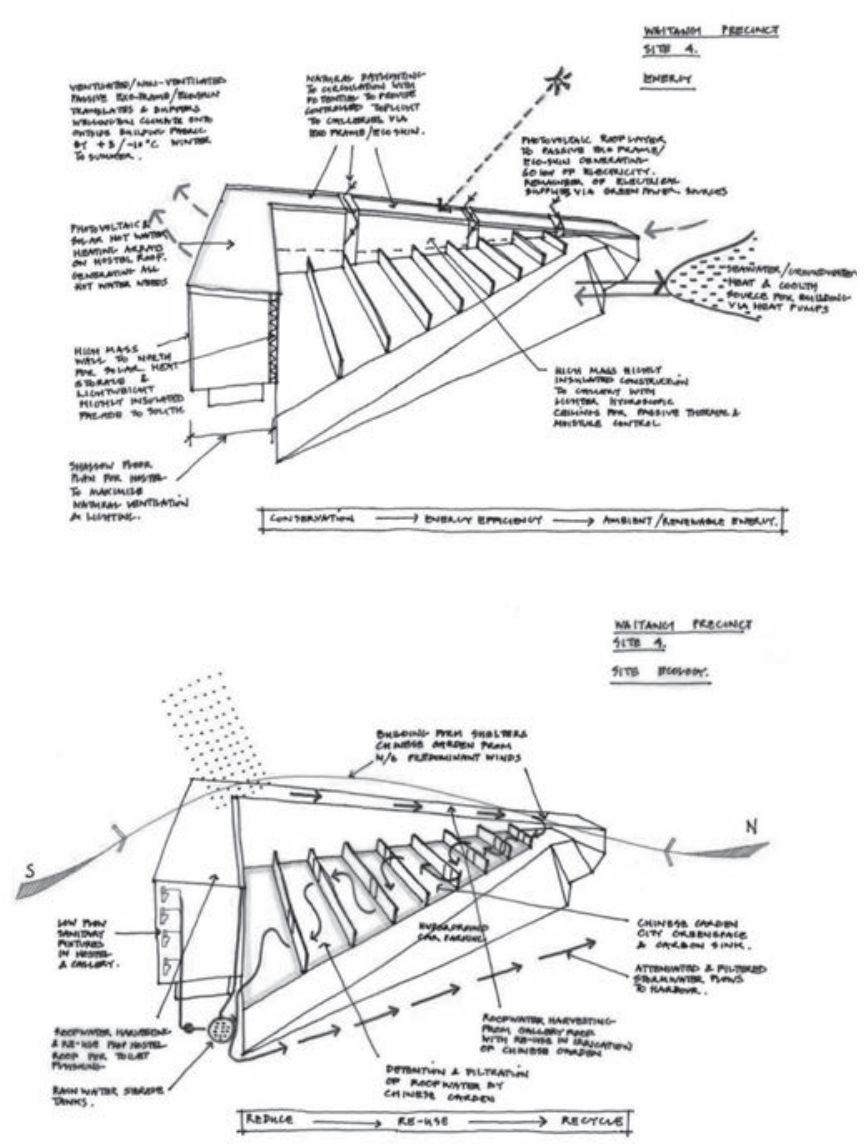

Sectional diagram showing the environmental strategies incorporated into the gallery building to achieve energy efficiency, including the use of renewable energy and the philosophy of reduce-reuse-recycle.

high city block
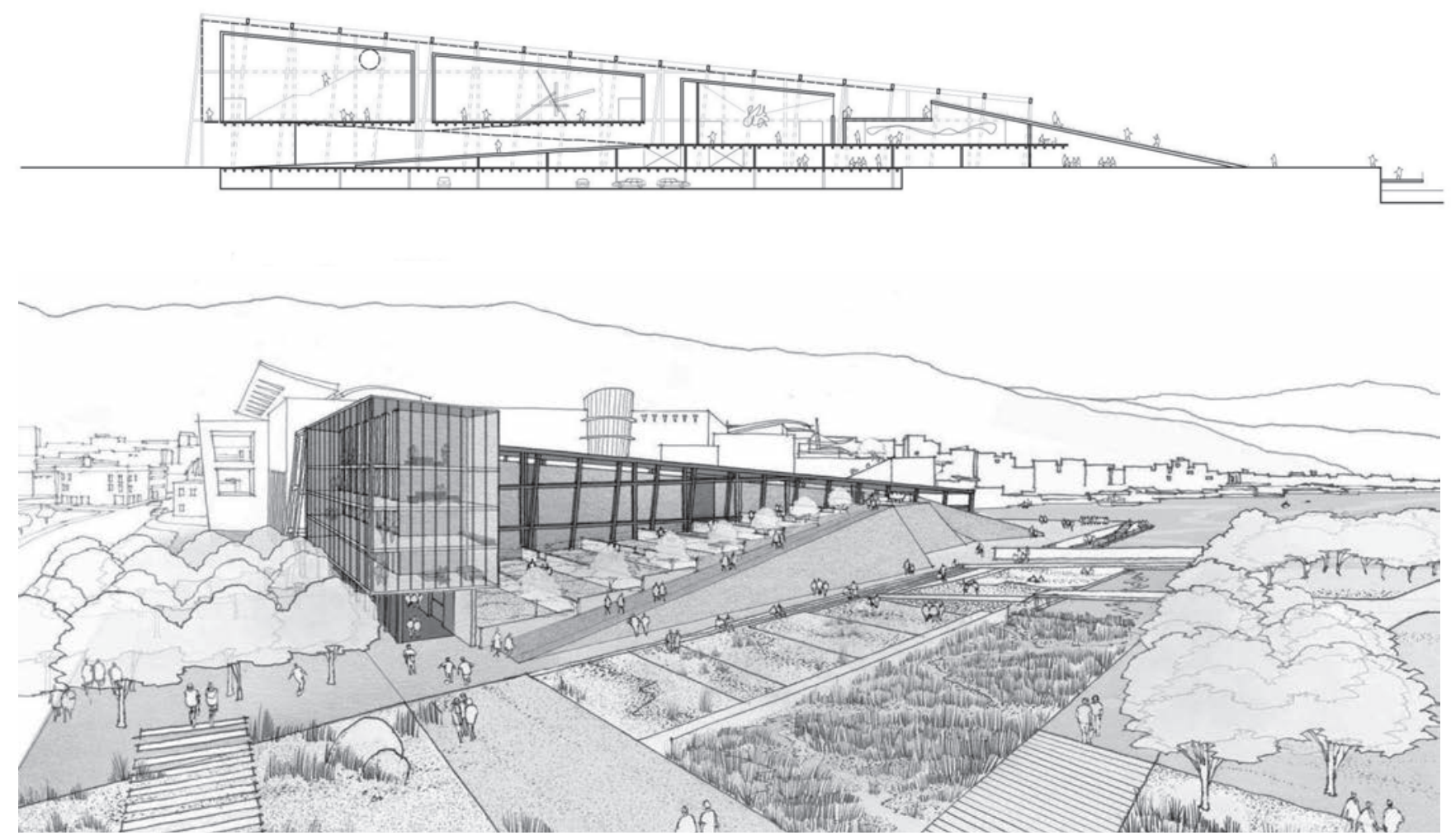

The city edge / gallery building, neighbouring Te Papa. 